\title{
マグネシウム合金単結晶の圧痕形成における すべりと双晶の役割
}

\author{
渡 邊 桃加 $1, * 1 \quad$ 北原弘 基 $2,3, * 2$ \\ 1熊本大学大学院自然科学教育部 \\ 2熊本大学パルスパワー科学研究所 \\ 3熊本大学先進マグネシウム国際研究センター \\ 4 熊本大学工学部 \\ J. Japan Inst. Met. Mater. Vol. 83, No. 12 (2019), pp. 458-464 \\ (C) 2019 The Japan Institute of Metals and Materials
}

高 松 洋平 1 ,*3

津志田雅之 ${ }^{4}$

安 藤 新 二 $^{3}$

\section{Roles of Slip and Twinning on Indentation Formations in Magnesium Alloy Single Crystals}

\author{
Momoka Watanabe ${ }^{1, * 1}$, Hiromoto Kitahara ${ }^{2,3, * 2}$, Yohei Takamatsu ${ }^{1, * 3}$, Masayuki Tsushida ${ }^{4}$ and Shinji Ando ${ }^{3}$ \\ ${ }^{1}$ Graduate School of Science and Technology, Kumamoto University, Kumamoto 860-8555 \\ ${ }^{2}$ Institute of Pulsed Power Science, Kumamoto University, Kumamoto 860-8555 \\ ${ }^{3}$ Magnesium Research Center, Kumamoto University, Kumamoto 860-8555 \\ ${ }^{4}$ Faculty of Engineering, Kumamoto University, Kumamoto 860-8555
}

Pure $\mathrm{Mg}, \mathrm{Mg}-0.5$ at $\% \mathrm{Al}, \mathrm{Mg}-0.5$ at $\% \mathrm{Zn}, \mathrm{Mg}-0.5$ at $\% \mathrm{Y}, \mathrm{Mg}-0.9$ at $\% \mathrm{Y}$, and pure $\mathrm{Zn}$ single crystals were applied to indentation tests using a spherical indenter to allow experimental investigation the roles both slips and twinning induce on the formation of indentation. When indented on (0001), all single crystals displayed indentation of circular morphology without slip lines and twins. Mg and Mg alloys' indentation sizes were found dependent on critical resolved shear stress (CRSS) for basal slip in (0001) indentations. Zn (0001) indentation size depends on CRSS for both basal and pyramidal slips. Conversely, when indented on (1010) and (1 $\overline{2} 10)$, all single crystals had indentations elongated to [0001] with basal slip lines around indentations. Also, $\{10 \overline{1} 2\}$ twins were observed in $\mathrm{Mg}-0.5$ at $\% \mathrm{Al}$ and $\mathrm{Mg}-0.5$ at $\% \mathrm{Zn}$ but were scarce in $\mathrm{Mg}-\mathrm{Y}$. Pure Zn displayed second order pyramidal slips. Sizes of both (1010) and (12) indentations were found dependent on CRSS for basal slips and for $\{10 \overline{1} 2\}$ twins. [doi:10.2320/jinstmet.J2019034]

(Received July 12, 2019; Accepted September 2, 2019; Published October 11, 2019)

Keywords: basal slip, second order pyramidal slip, $\{10 \overline{1} 2\}$ twin, critical resolved shear stress

\section{1. 緒言}

六方晶 (hcp) 金属には, マグネシウム, チタンおよび带鉛 など工業的に重要な金属が多く存在する。しかしながら, hcp 金属は, 立方晶金属と比較して, 変形に強い結晶方位依 存性を持つため, その変形機構は十分に解明されていない. このような変形機構の調査を行うために, hcp 金属単結晶を 用いた引張試験 ${ }^{1,2)}$, 圧縮試験 ${ }^{3)}$, 純粋せん断試験 ${ }^{4)}$ および疲 労試験 5 ,6) が行われ, 活動するすべり系と双晶系および各臨 界分解せん断応力 (CRSS) が報告されている.これらの試験 では, 一軸の荷重により単結晶全体を変形させている. とこ ろで, 多結晶体の変形では, 方位の異なる結晶粒が 3 次元且 つ相互に拘束しているため, 個々の結晶粒内で応力もしくは ひずみの勾配があると考えられる。そこで，インデンテー ション試験を用いた純マグネシウム単結晶の局所変形挙動に

\footnotetext{
*1 熊本大学大学院生 (Graduate Student, Kumamoto University)

*2 Corresponding author, E-mail: kitahara@msre.kumamoto-u.ac.jp

*3 熊本大学大学院生, 現在 : (株) 神戸製鋼所 (Graduate Student, Kumamoto University, Present address: Kobe Steel, Ltd.)
}

関する研究が行われている. Kitahara $ら^{7)}$ は，純マグネシウ ム単結晶の低指数面に球圧子を圧入し, 活動するすべり系や 双晶系および圧痕形状に異方性があることを明らかにしてい る.さらに, 結晶塑性有限要素法 (CPFEM)により, (0001) に圧入した場合は, 底面すべりと $(c+a)$ 錐面すべりが活動し, (1100) および $(11 \overline{2} 0)$ に圧入した場合は，底面すべりや $\{10 \overline{1} 2\}$ 双晶が活動することで圧痕が形成されると報告している. Nayyeri ら ${ }^{8)}$ は, 純マグネシウム多結晶の粗大粒に対して, [0001] から約 $9^{\circ}$ 傾斜した方向に球圧子を圧入し，底面す心゙ りと $\{10 \overline{1} 2\}$ 双晶の活動により圧痕が形成されることを報告 している，また，CPFEMにより圧痕直下の底面すべりの挙 動について検討を行っている. 以上のように, 計算機シミュ レーションにより圧痕直下の変形挙動は予想されているが, 実験的な確証は得られていない.

マグネシウムにアルミニウム ${ }^{9-11)}$, 亜鉛 ${ }^{12,13)}$ およびイット リウム ${ }^{13,14)}$ を添加すると, 底面すべりおよび 2 次錐面すべり の CRSS が変化することが報告されている．また，hcp 金属 の代表的な変形双晶である $\{10 \overline{1} 2\}$ 双晶は $c / a=\sqrt{3}$ を境に, 双晶発生の荷重軸方向が逆になることが知られている ${ }^{15,16)}$. $c / a=1.623$ のマグネシウムでは, $c$ 軸引張で $\{10 \overline{1} 2\}$ 双晶が発 
生するが, $c / a=1.856$ の亜鉛では $c$ 軸圧縮で $\{10 \overline{1} 2\}$ 双晶が発 生する。そのため, CRSS の異なるマグネシウム合金や双晶 発生方向の異なる亜鉛に対して同様のインデンテーション試 験を行えば, 純マグネシウムと異なる変形挙動を示し, 変形 挙動の違いから圧痕直下の変形挙動を実験的に推定できるこ とが期待される。そこで本研究では, 純マグネシウム, $\mathrm{Mg}-$ $\mathrm{Al}, \mathrm{Mg}-\mathrm{Zn}, \mathrm{Mg}-\mathrm{Y}$ 合金および純亜鉛単結晶のインデンテー ション試験を行い, 圧痕サイズとすべりや双晶の CRSS の相 関を基に, 圧痕直下の変形挙動について検討を行った.

\section{2. 実 験 方 法}

本研究では, 純マグネシウム, $\mathrm{Mg}-0.5$ at $\% \mathrm{Al}, \mathrm{Mg}-0.5$ at $\% \mathrm{Zn}, \mathrm{Mg}-0.5$ at $\% \mathrm{Y}, \mathrm{Mg}-0.9$ at $\% \mathrm{Y}$, 純亜鉛の単結晶試料 を用いた。（以下， Mg，05Al，05Zn，05Y，09Y および Zn とする. ) Mg と Zn は, いずれも純度が $99.99 \%$ のンゴット を用いた。ママグネシウム合金インゴットは，高周波誘導溶解 炬を用いて作製した。これらのインゴットと種結晶を黒鉛る つぼに入れ，改良型ブリッジマン法により単結晶をそれぞれ 作製した。作製後の単結晶の組成は，高周波誘導結合プラズ マ発光分光分析装置 ((株) 日立ハイテクサイエンス製)により 確認した．圧子圧入面は，(0001)， $\{10 \overline{1} 0\}$ および $\{1 \overline{2} 10\}$ とな るように X 線背面反射ラウエ法を用いて方位解析を行った. $\mathrm{Mg}$ および $\mathrm{Mg}$ 合金の研磨液の組成は, $\mathrm{HNO}_{3}: \mathrm{H}_{2} \mathrm{O}_{2}$ : $\mathrm{C}_{2} \mathrm{H}_{5} \mathrm{OH}=5: 7: 20$ とし, $\mathrm{Zn}$ の場合, $\mathrm{HNO}_{3}: \mathrm{H}_{2} \mathrm{O}_{2}: \mathrm{C}_{2} \mathrm{H}_{5} \mathrm{OH}=$ 1: 1: 4 とした. 化学研磨後, 切断や研磨におけるひずみを除 去するために, $\mathrm{Mg}$ 合金単結晶に対して, 8 サイクルの熱サ イクル焼鈍を行った。熱サイクル焼鈍では, $673 \mathrm{~K}$ および $723 \mathrm{~K}$ の間での昇温と降温を 1 サイクルとした. 各温度での 保持時間は $3.6 \mathrm{ks}$ であり, 昇温および降温速度は $6.9 \times 10^{-3}$ $\mathrm{K} / \mathrm{s}$ である。焼鈍後, 試験面表面に対して上述の研磨液を用 いて化学研磨を行い，表面の污れや酸化膜を除去した，各試 験片の厚みは, JIS Z2243 に準拠し, 圧痕深さの 8 倍以上と した ${ }^{17)}$ 。硬さ試験機には, (株)島津製作所製の微小硬度計 $\mathrm{M}$ 型を用いた。圧子として直径 $1.0 \mathrm{~mm}$ のダイヤモンド球圧 子を用い, 負荷荷重を 0.98-4.90 N, 保持時間を $15 \mathrm{~s}$ とし,
室温で (0001)，(1010) および (1210) にそれぞれ 4-5 回の試験 を行った. 試験後, 各面において 2 方向について圧痕の直径 を計測した。 また, 圧痕周辺に発生した $\{10 \overline{1} 2\}$ 双晶の面積 も測定した. 双晶面積は, 光学顕微鏡写真の双晶部分を切り 取り計測した. インデンテーション試験後, 圧痕および圧痕 周りの変形組織を光学顕微鏡で観察し, 各面の圧痕周りに発 生したすべり線と双晶について解析を行った. Znの変形挙

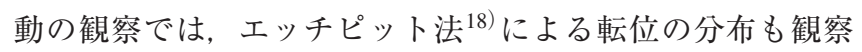
した.

\section{3. 結 果}

Fig. 1 と Fig. 2 に, Mg, 05Al, 05Zn, 05Y, 09Y および Zn の $(0001)$ と $(10 \overline{10} 0)$ における圧痕の光学顕微鏡写真を示す. 負荷荷重は $4.90 \mathrm{~N}$ である。(0001) では，全ての圧痕が円形 となった。また圧痕内部やその周辺おいて, すべり線や双晶 はほとんど観察されなかった。一方，(1010) では， Mg, 05Al および 05Znの圧痕は [0001] に伸長した楕円形状とな り，圧痕周辺には底面にほぼ平行なすべり線および双晶のみ が観察された．イットリウムを添加した 05Yと09Y の圧痕 も [0001] に伸長したが，その割合は 05Al や 05Zn に比べ小 さかった．特に，05Yと09Yを比較すると，09Y の圧痕形 状は，05Yに比べ円形に近いことが分かる. Mineta ら ${ }^{19)} も$ また, $\mathrm{Mg}-1.3$ at $\% \mathrm{Y}$ と $\mathrm{Mg}-2.3$ at $\% \mathrm{Y}$ 合金単結晶に対して球 圧子圧入試験を行い, イットリウム添加量の増加に伴い, 圧 痕形状が円形に近づくことを報告している。05Y の圧痕周辺 では少量のすべり線と双晶のみが観察されたが，09Y の圧痕 周辺では少量のすべり線のみが観察され，双晶はほとんど観 察されなかった，Znの圧痕もまた，[0001]に伸長した楕円 形状となったが, 圧痕周辺では, すべり線のみが観察され, 双晶は観察されなかった。 $\mathrm{Mg}$ や $\mathrm{Mg}$ 合金単結晶において観 察された双晶は, [12 10$]$ に対してほぼ平行または約 $38^{\circ}$ 傾い ていた。これらの双晶は, $\{10 \overline{1} 2\}$ 双晶の $(10 \overline{1} 0)$ におけるト レースと一致するため, $\{10 \overline{1} 2\}$ 双晶であった. Fig. 3 に, $\mathrm{Mg}, 05 \mathrm{Al}, 05 \mathrm{Zn}, 05 \mathrm{Y}, 09 \mathrm{Y}$ および Znの (1210)における圧 痕の光学顕微鏡写真を示す。圧痕形状や観察されるすべり線
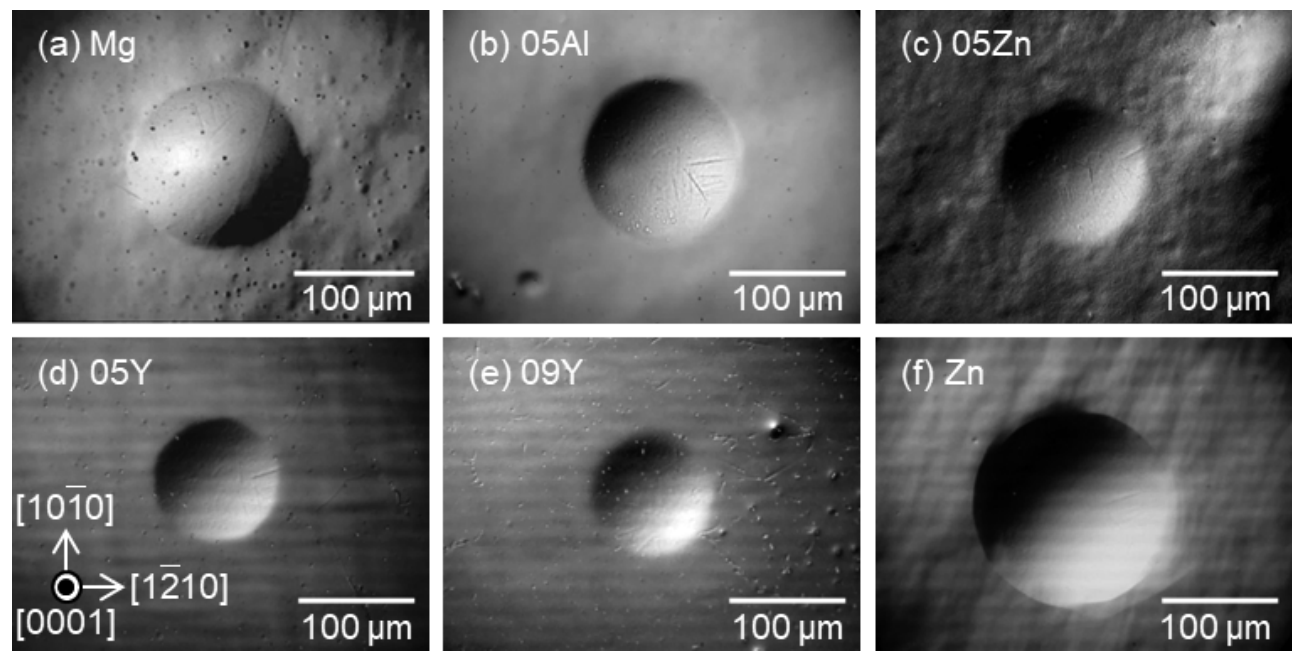

Fig. 1 Optical micrographs of indentations on (0001) in (a) Mg, (b) 05Al, (c) 05Zn, (d) 05Y, (e) 09Y and (f) Zn single crystals when indented at $4.90 \mathrm{~N}$. 

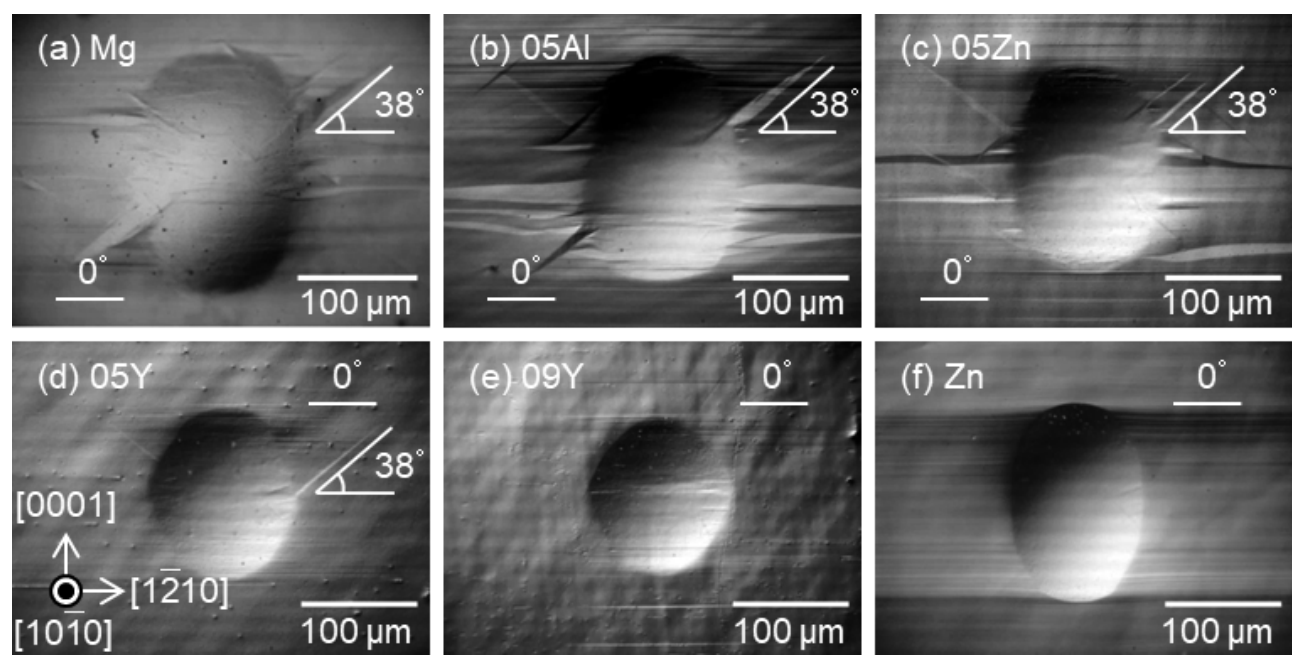

Fig. 2 Optical micrographs of indentations on (1010) in (a) Mg, (b) 05Al, (c) 05Zn, (d) 05Y, (e) 09Y and (f) Zn single crystals when indented at $4.90 \mathrm{~N}$.
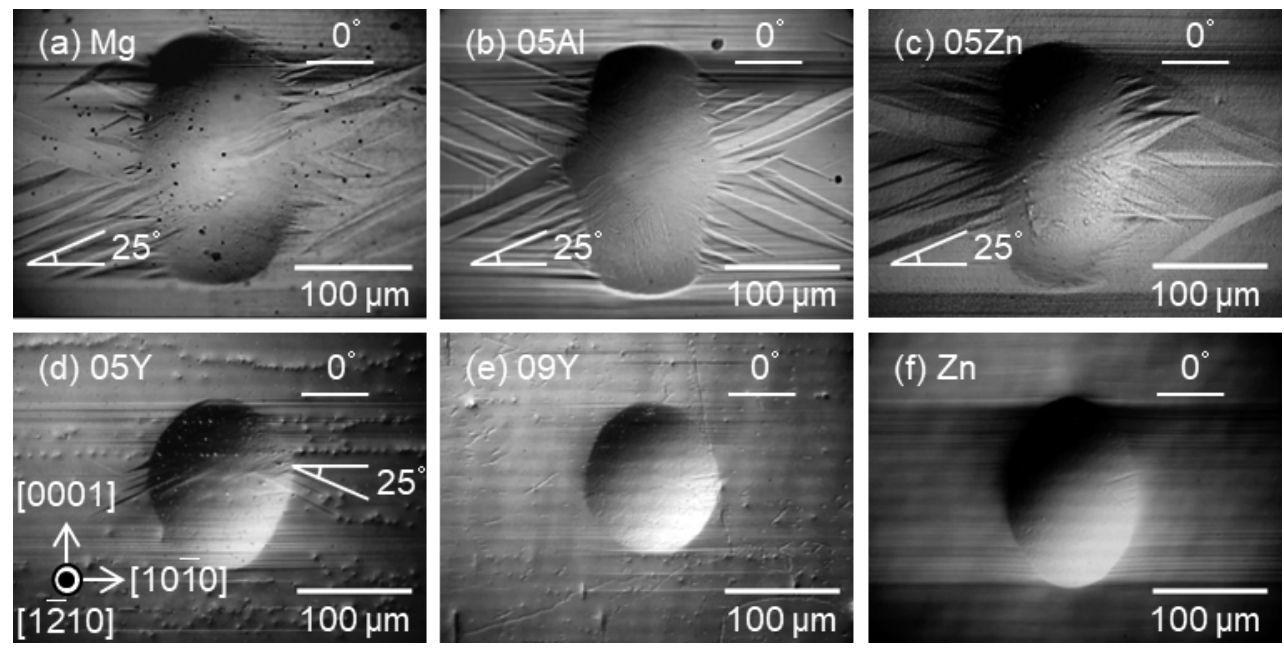

Fig. 3 Optical micrographs of indentations on (12̄10) in (a) Mg, (b) 05Al, (c) 05Zn, (d) 05Y, (e) 09Y and (f) Zn single crystals when indented at $4.90 \mathrm{~N}$.

と双晶は, $(10 \overline{1} 0)$ の結果と同様であり, 変形挙動の方位依存 性は観察されなかった。

Fig. 4 に， Znの (12 10$)$ に $4.90 \mathrm{~N}$ で導入した圧痕周辺にお けるエッチピットの光学顕微鏡写真を示す. 圧痕周辺には多 数のピットが確認でき, 圧痕の上下左右に多数のピットが集 中していることが分かる. 底面に平行なピット列と [1010]に 対して $58^{\circ}$ 傾いたピット列が観察された。 圧痕周辺に多数見 られた底面に平行なピット列は, 純亜鉛においても容易に活

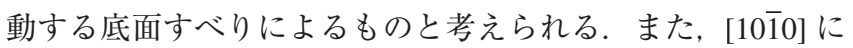
対して $58^{\circ}$ 傾いたピット列は, 2 次錐面すべりのトレースに 一致するため, 2 次錐面すべりが活動したと考えられる。し かしながら， 2 次錐面すべりによるピット列は，底面すべり によるピット列に比べて少量であったため, 圧痕の形成には あまり寄与していないと考えられる。 また, (1010)において も，底面すべりおよび 2 次錐面すべりによるものと考えられ るピット列が観察されたが, 2 次錐面すべりによるピット列 は少量であった。

Fig. 5, Fig. 6 および Fig. 7 に，各試料における(0001), (10)10) および $(1 \overline{2} 10)$ の圧痕サイズと負荷荷重の関係を示す. 負荷荷重が $0.98 \mathrm{~N}, 1.96 \mathrm{~N}$ および $4.90 \mathrm{~N}$ において, (0001)

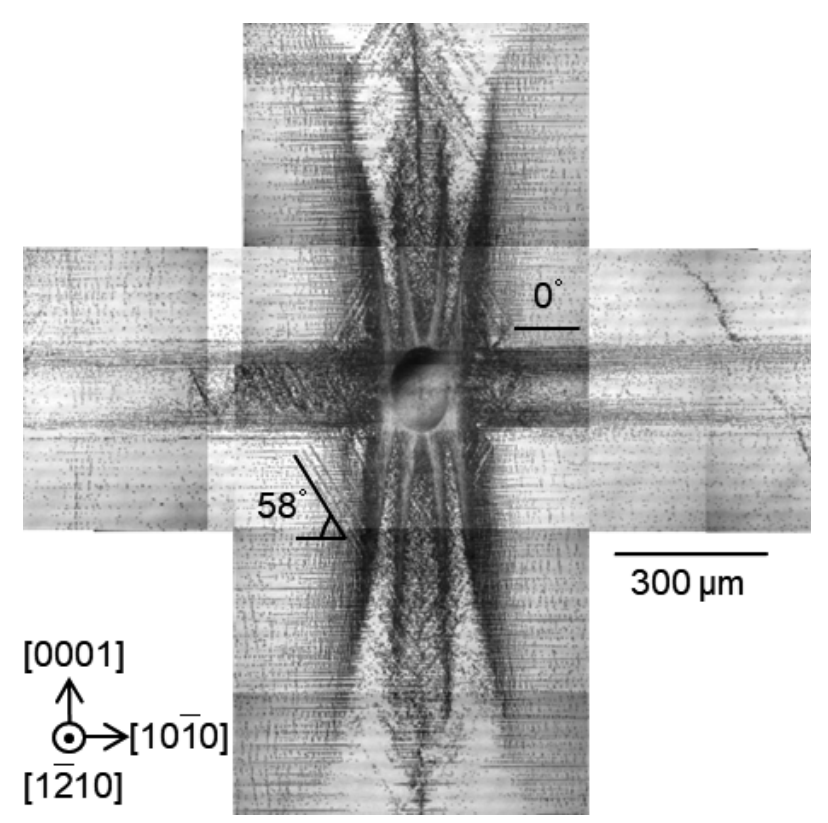

Fig. 4 Optical micrographs of etch pits on (12̄10) in Zn single crystals when indented at $4.90 \mathrm{~N}$. 
$\mathrm{O}[10 \overline{10}] \quad \square[1 \overline{2} 10]$
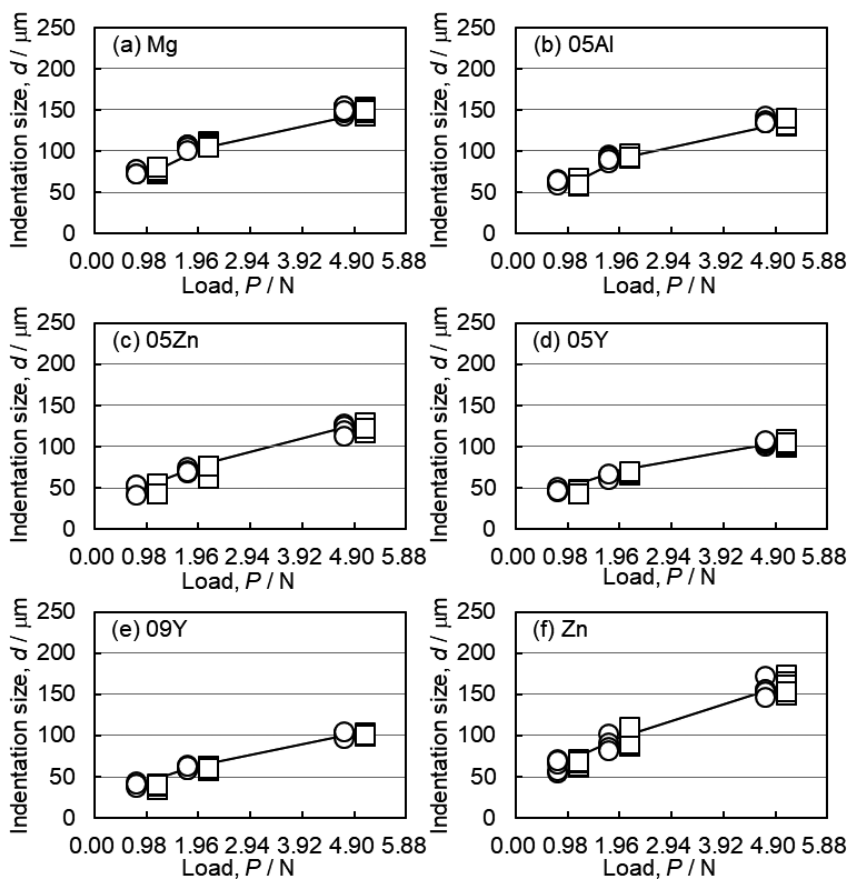

Fig. 5 Relationship between indentation size and indentation load of (a) $\mathrm{Mg}$, (b) 05 Al, (c) 05Zn, (d) 05Y, (e) $09 \mathrm{Y}$ and (f) $\mathrm{Zn}$ on (0001).

$\bigcirc[0001] \square[1 \overline{2} 10]$
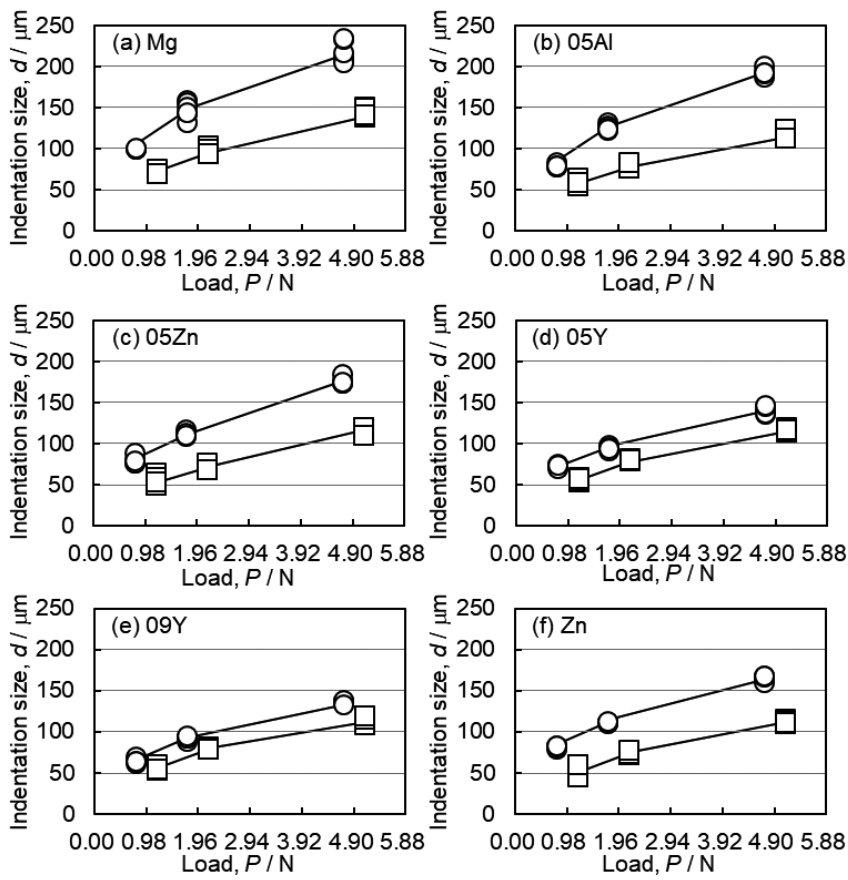

Fig. 6 Relationship between indentation size and indentation load of (a) $\mathrm{Mg}$, (b) 05Al, (c) 05Zn, (d) 05Y, (e) 09Y and (f) Zn on (10̄̄0).

の圧痕サイズは $[10 \overline{1} 0]$ と $[1 \overline{2} 10]$ の直径をそれぞれ測定し， (1010) と $(1 \overline{2} 10)$ の楕円形状の圧痕では, 長軸と短軸をそれぞ れ計測した。ここで，各プロットの位置は，互いに重ならな いように負荷荷重の左右に配置している. Fig. 5 に示すよう に, $\mathrm{Mg}$ と $\mathrm{Mg}$ 合金の (0001) 圧痕サイズを比較すると, 合金 元素の添加により圧痕が小さくなることが分かる．圧痕サイ ズは, $\mathrm{Mg}, 05 \mathrm{Al}, 05 \mathrm{Zn}, 05 \mathrm{Y}, 09 \mathrm{Y} の$ 順に小さくなった. また, $\mathrm{Mg}$ と $\mathrm{Zn}$ の圧痕サイズに大きな差はなかった，全て
$\mathrm{O}[0001] \quad \square[10 \overline{10}]$
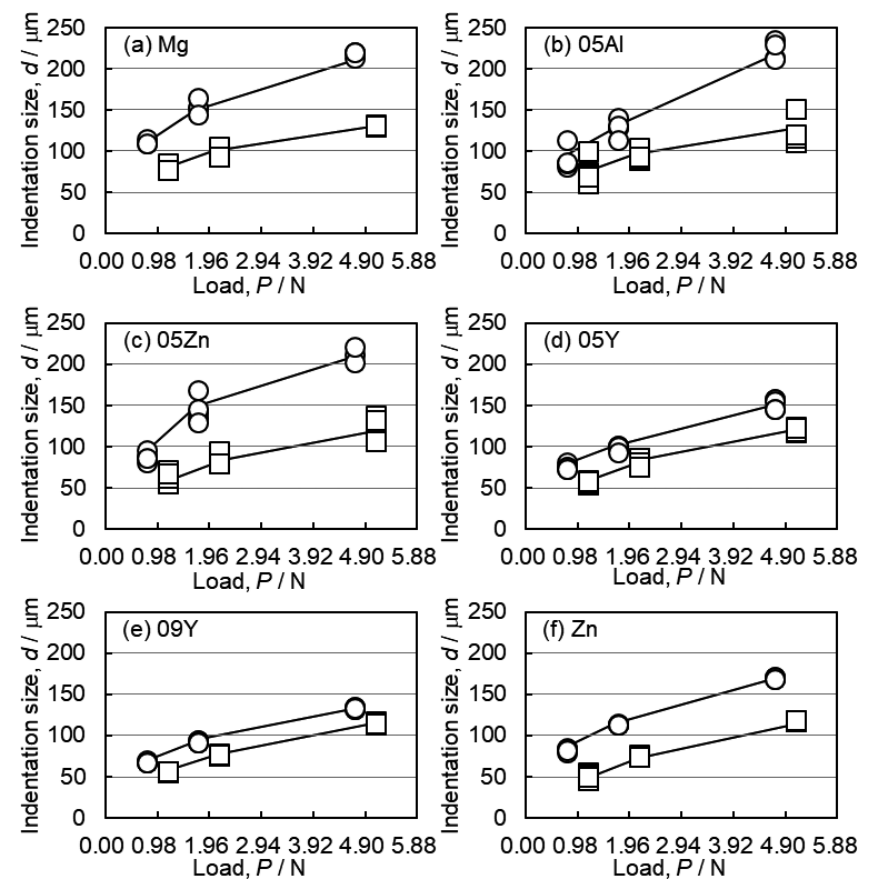

Fig. 7 Relationship between indentation size and indentation load of (a) $\mathrm{Mg}$, (b) 05Al, (c) 05Zn, (d) 05Y, (e) 09Y and (f) Zn on (12) 10$)$.

の試料において, $[10 \overline{1} 0]$ と $[1 \overline{2} 10]$ の圧痕サイズは, ほぼ同じ であり, 圧痕サイズの方位依存性は非常に小さいことが分 かった. Fig. 6 および Fig. 7 に示すように，圧痕面が (1010) および $(1 \overline{2} 10)$ の場合，全ての試料において，[0001]の圧痕少 イズは $[1 \overline{2} 10]$ および $[10 \overline{1} 0]$ よりも長いことが分かった. $\mathrm{Mg}$, $05 \mathrm{Al}$ および $05 \mathrm{Zn}$ の圧痕の長径/短径比を求めた結果, 圧痕 面が (10̄0) で負荷荷重が $4.90 \mathrm{~N}$ の場合 $1.54,1.63$ および 1.52 となり, 長径/短径比には差がほとんど見られなかった. 一方，05Y および 09Yでは， 1.20 および 1.19 となり， Mg の值よりも小さな值となった. これらの值は，1に近くなる ほど圧痕形状は円形に近くなることを示している。したがっ て, 長径/短径比から 05Y や 09Y は 05Al や 05Znよりも異方 性が小さいことが分かった。このような傾向は圧痕面が (1210) で負荷荷重が $4.90 \mathrm{~N}$ の場合も同様であった. Fig. 6(f)

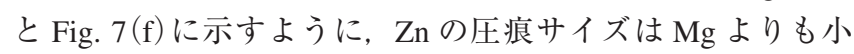
さいことが分かった.

\section{4. 考察}

\section{$4.1(0001)$ の圧痕サイズとすべりの関係}

(0001) では, 全ての圧痕周辺で, すべり線も双晶も観察さ れなかった。 そのため, 圧痕は, 圧痕直下のすべり変形によ り形成したと考えられる。そこで，圧痕形成に関与したすべ り系を調査するために, 負荷荷重 $4.90 \mathrm{~N}$ での圧痕サイズと 底面すべりおよび 2 次錐面すべりの CRSS の比較を行った. Fig. 8 に, (0001) における各試料の (a) 圧痕サイズ, (b) 底面 すべりおよび (c) 2 次錐面すべりの CRSS を示す. $\mathrm{Mg}$ と $\mathrm{Mg}$ 合金を比較すると, 合金元素の添加により05Al, 05Zn, 05Y，09Yの順に圧痕は小さくなり，底面すべりの CRSS は 同じ順で上昇する。一方, 2 次錐面すべりの CRSS に大きな 

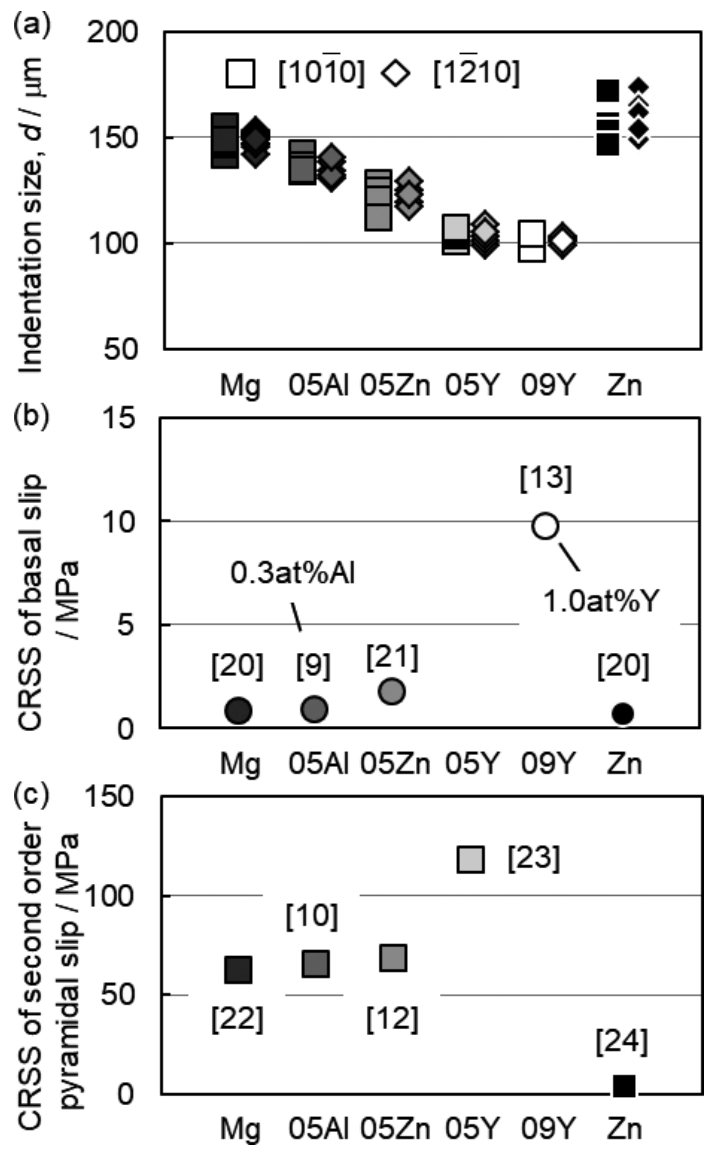

Fig. 8 (a) Indentation size on (0001), (b) CRSS for basal slip and (c) CRSS for second order pyramidal slip in $\mathrm{Mg}, \mathrm{Mg}$ alloy and $\mathrm{Zn}$ single crystals.

変化は見られない。このように $\mathrm{Mg}$ と $\mathrm{Mg}$ 合金を比較した場 合，底面すべりのCRSS と圧痕サイズが良い相関を示した。 次に, $\mathrm{Mg}$ と $\mathrm{Zn}$ を比較すると, $\mathrm{Zn}$ の圧痕サイズは $\mathrm{Mg}$ より 大きく, Znの 2 次錐面すべりの CRSS は, Mg の CRSS の 1/10 以下である。一方, 底面すべりの CRSS はほぼ同程度 である。このように, $\mathrm{Mg}$ と $\mathrm{Zn}$ では, 底面すべりの CRSS は近く，その活動は同程度であり，これに2 次錐面すべりの 活動が加わるため, Zn の圧痕サイズが $\mathrm{Mg}$ より大きくなっ たと考えられる. Fig. 9 に，(a) Mg および $\mathrm{Mg}$ 合金と (b) $\mathrm{Zn}$ の (0001) の圧痕形成メカニズムの模式図を示す.（a）では, 圧子の圧入とともに, 底面は曲がることで, 底面にせん断力 がかかる，底面すべりの CRSS は非常に小さいため，容易に

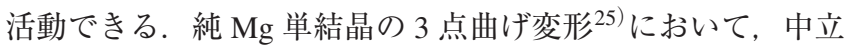
面と底面が平行な場合でも底面すべりは容易に活動すること が報告されている。（b） Zn では，底面すべりに加えて，比較 的 CRSS の低い 2 次錐面すべりが圧痕直下で活動する。以上 のことから, $\mathrm{Mg}$ と $\mathrm{Mg}$ 合金の (0001)における圧痕サイズ は, 主すべりである底面すべりの CRSS に大きく依存するこ とが分かった。一方, Znの (0001) における圧痕サイズは, 底面すべりと 2 次錐面すべりの CRSS に依存することが分 かった. $\mathrm{Mg}$ と $\mathrm{Mg}$ 合金の (0001)の圧痕形成は, 主に底面す ベりの活動によるものであり，Znの (0001) の圧痕形成は, 底面すべりと 2 次錐面すべりの活動によるものと考えられ る。 (a)

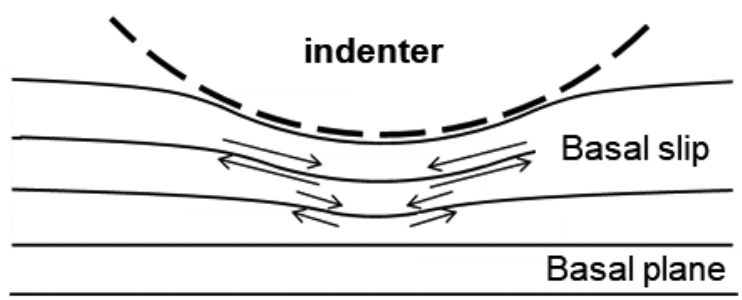

(b)

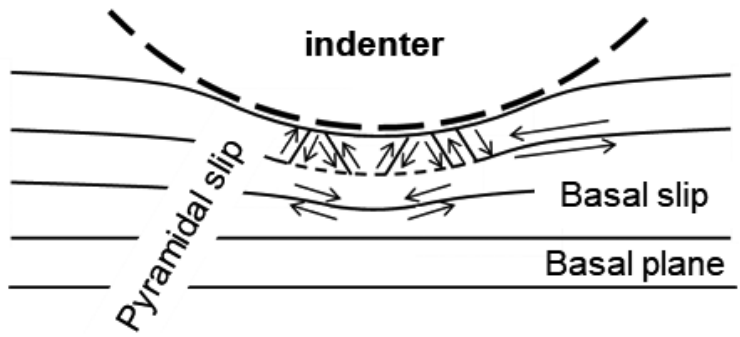

Fig. 9 Schematic illustrations of deformation behavior underneath (0001) indentations in (a) $\mathrm{Mg}$ and $\mathrm{Mg}$ alloy, and (b) Zn single crystals.
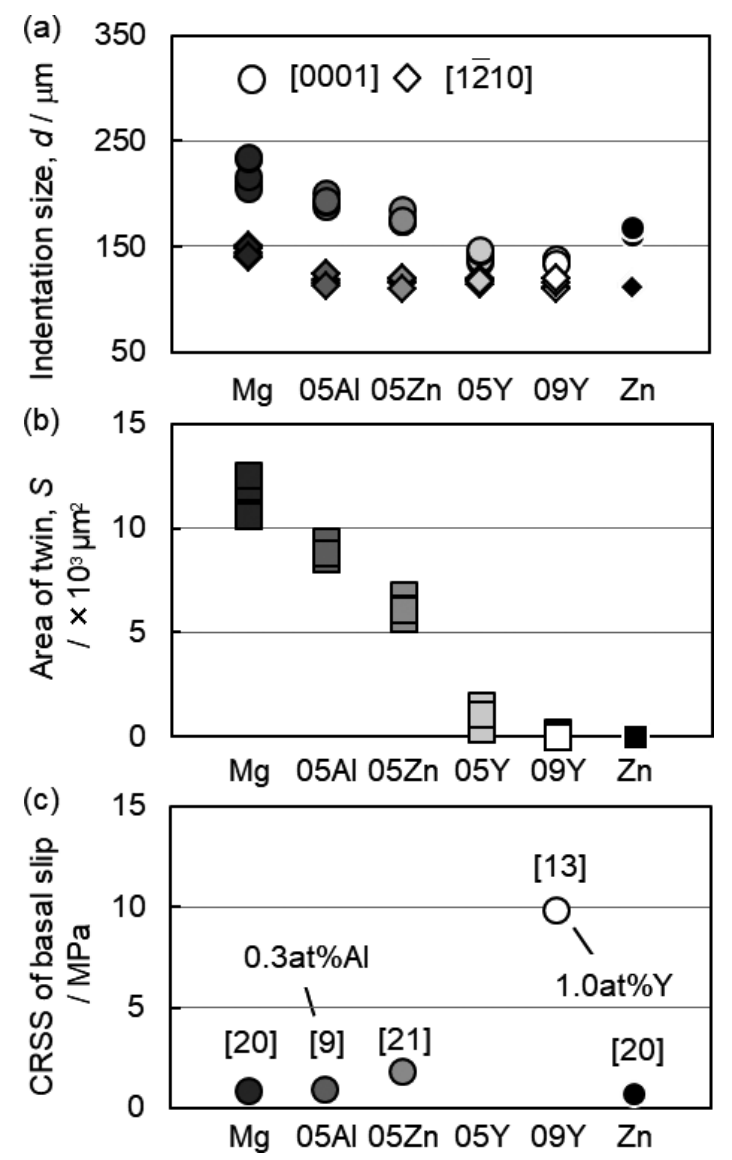

Fig. 10 (a) Indentation size on (1010), (b) area of twin and (c) CRSS for basal slip in $\mathrm{Mg}, \mathrm{Mg}$ alloy and $\mathrm{Zn}$ single crystals.

$4.2(10 \overline{10})$ と (1210) における圧痕サイズと双晶および底面 すべりの関係

(1010) および $(1 \overline{2} 10)$ の圧痕は，[0001] に伸長し，圧痕周辺 には双晶とすべり線が観察された. Fig. 10 と Fig. 11 に， $(10 \overline{1} 0)$ と $(1 \overline{2} 10)$ における各試料の (a) 圧痕サイズ, (b) 圧痕周 

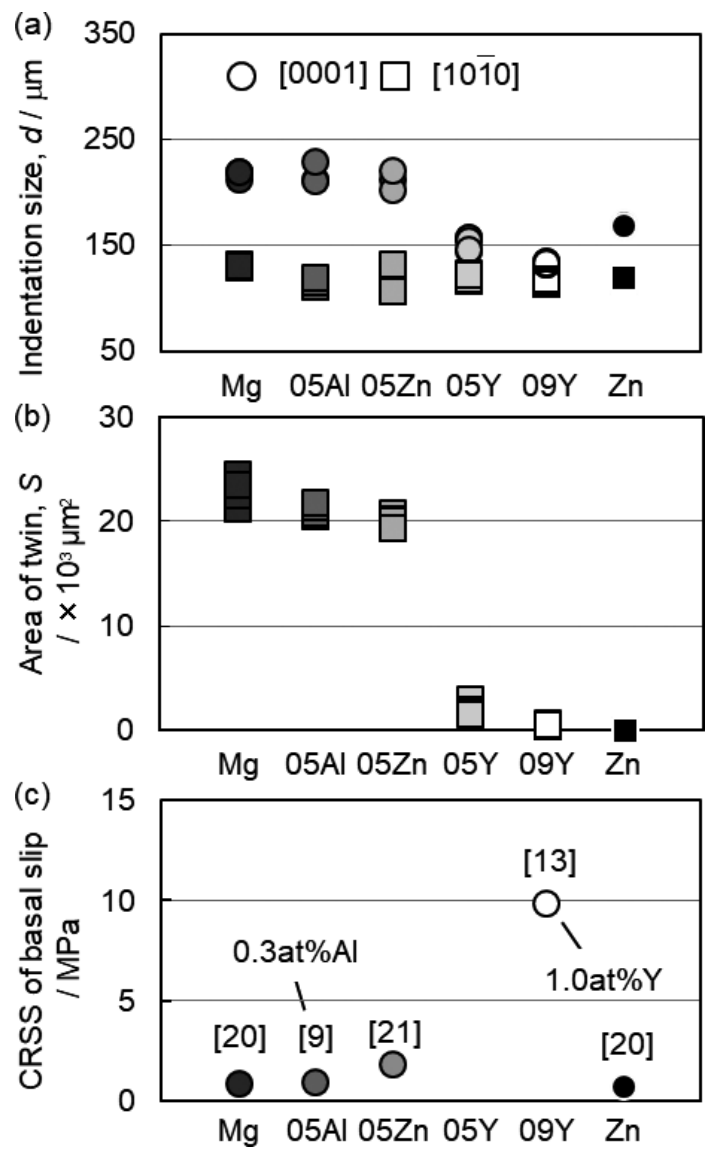

Fig. 11 (a) Indentation size on (12̄10), (b) area of twin and (c) CRSS for basal slip in Mg, Mg alloy and Zn single crystals.

辺で観察された $\{10 \overline{1} 2\}$ 双晶の面積および $(\mathrm{c})$ 底面すべりの CRSS を示す. $\mathrm{Mg}$ と Zn を比較すると, どちらの面において も $\mathrm{Zn}$ の圧痕サイズは $\mathrm{Mg}$ より小さかった。また， Znでは $\{10 \overline{1} 2\}$ 双晶は観察されなかったため, 双晶面積の大小関係も 圧痕サイズと同様となった。一方, $\mathrm{Mg}$ と $\mathrm{Zn}$ の底面すべり の CRSS は同程度である. 以上のことから, $\mathrm{Mg}$ と $\mathrm{Zn}$ の圧 痕サイズの差は, $\{10 \overline{1} 2\}$ 双晶の活動に起因すると考えられ る. 次に, $\{10 \overline{1} 2\}$ 双晶が観察されなかった $09 \mathrm{Y}$ と $\mathrm{Zn}$ を比較 すると，どちらの面においても09Y の圧痕サイズがより小 さい，一方，Znの底面すべりの CRSS は，09Y の CRSS の 1/10 以下である. したがって, 09Y と Zn の圧痕サイズの差 は，底面すべりによるものであると考えられる．以上のこと から, $\mathrm{Mg}$ 単結晶の $(10 \overline{1} 0)$ と (12 10$)$ における圧痕サイズは, 底面すべりおよび $\{10 \overline{1} 2\}$ 双晶の両方の活動により決まり, 合金元素の添加による底面すべりおよび $\{10 \overline{1} 2\}$ 双晶の両方 の CRSS が上昇することで，圧痕サイズが小さくなると考え られる. $\mathrm{Mg}, 05 \mathrm{Al}$ および $05 \mathrm{Zn}$ を比較すると, $\mathrm{Al}$ および $\mathrm{Zn}$ の添加で $(10 \overline{1} 0)$ における [0001] の圧痕の直径は減少してい

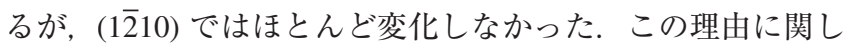
ては今後の検討課題である.

09Y の双晶面積は，05Y に比べ小さくなっていた，そのた め, イットリウム添加量の増加により双晶の CRSS が向上し たと考えられる. 峯田ら ${ }^{26)}$ は, $\mathrm{Mg}-0.8$ at\% $\%$ の圧縮試験に おいて $\{10 \overline{1} 2\}$ 双晶の CRSS は $31.0 \mathrm{MPa}$ と見積もり， Mg にお

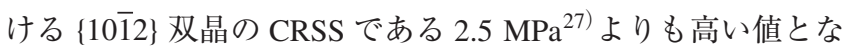

ることを報告している. また，Fig. 2 および Fig. 3 に示すよ うに，イットリウム添加量の増加に伴い，圧痕が楕円形状か ら円形状に変化していることから, すべりの活動量が変化し たと考えられる. Rikihisa ら ${ }^{14)}$ は, イットリウムを種々変化 させた $\mathrm{Mg}-\mathrm{Y}$ 合金単結晶の引張試験を行った結果, イット リウムを添加すると，2 次錐面すべりではなく 1 次錐面すべ りが活動し，イットリウム添加量の増加に伴い，その CRSS が上昇することを報告している，そのため，05Yと09Yの 圧痕形状の違いは, 1 次錐面すべりの活動の違いによるもの と考えられる．以上のように，試料により非底面すべりの活 動量は異なるが, $(10 \overline{1} 0)$ と $(1 \overline{2} 10)$ の圧痕サイズは主すべりで ある底面すべりと双晶の CRSS に大きく依存することが明ら かとなった。

\section{5. 結 言}

純マグネシウム, $\mathrm{Mg}-0.5$ at $\% \mathrm{Al}$ 合金, $\mathrm{Mg}-0.5$ at $\% \mathrm{Zn}$ 合 金, $\mathrm{Mg}-0.5$ at $\% \mathrm{Y}$ 合金, $\mathrm{Mg}-0.9$ at $\% \mathrm{Y}$ 合金および純亜鉛単 結晶の球圧子インデンテーション試験を行い, その変形挙動 を調査した結果, 以下のことが明らかとなった。

(0001) では，全ての圧痕が円形であった。また，圧痕周辺 にはすべり線と双晶は観察されなかった. $\mathrm{Mg}$ と $\mathrm{Mg}$ 合金の (0001) の圧痕サイズは, 底面すべりの臨界分解せん断応力 (CRSS) に大きく依存し, 純亜鉛の (0001) の圧痕サイズは,

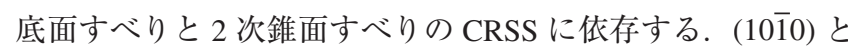
(1210) の圧痕は, [0001] 方向に伸長した楕円形状となった. $\mathrm{Mg}-\mathrm{Al}$ と $\mathrm{Mg}-\mathrm{Zn}$ の圧痕周辺には底面すべりと $\{10 \overline{1} 2\}$ 双晶が 観察された．イットリウムを添加すると， $\{10 \overline{1} 2\}$ 双晶の CRSS が上昇するため, 双晶はほとんど観察されなかった. さらにイットリウム添加量が増加すると，1 次錐面すべりの 活動量が変化し, 圧痕の形状が円形に近づいた。一方, 純亜 鉛の圧痕周辺では $\{10 \overline{1} 2\}$ 双晶は観察されず，底面すべりに 起因する多量のエッチピットと 2 次錐面すべりに起因する微 量のエッチピットが観察された。 $(10 \overline{10})$ と $(1 \overline{2} 10)$ の圧痕サイ ズは，主すべりである底面すべりと $\{10 \overline{1} 2\}$ 双晶の CRSS に大 きく依存する.

本研究の一部は, 科学研究費補助金( 課題番号: $15 \mathrm{~K} 06425)$, 公益財団法人軽金属奨学会の補助金の助成を受 けたものである.ここに深く感謝の意を表する。

\section{文献}

1) H. Yoshinaga and R. Horiuchi: Trans. JIM 5 (1964) 14-21.

2) H. Tonda, S. Fujiwara and T. Kawasaki: J. Japan Inst. Metals 47 (1983) 927-932.

3) T. Kitahara, S. Ando, M. Tsushida, H. Kitahara and H. Tonda: Key Eng. Mater. 345-346 (2007) 129-132.

4) K. Fukuda, Y. Koyanagi, M. Tsushida, H. Kitahara, T. Mayama and S Ando: Mater. Trans. 58 (2017) 587-591.

5) N. Iida, S. Ando, M. Tsushida, H. Kitahara and H. Tonda: Key Eng. Mater. 345-346 (2007) 307-310.

6) Y. Kido, A. Nakamura, S. Tsunoda, M. Tsushida, H. Kitahara and S Ando: Mater. Trans. 59 (2018) 1739-1746.

7) H. Kitahara, T. Mayama, K. Okumura, Y. Tadano, M. Tsushida and S. Ando: Acta Mater. 78 (2014) 290-300.

8) G. Nayyeri, W.J. Poole, C.W. Sinclair, S. Zaefferer, P.J. Konijnenberg 
and C. Zambaldi: Mater. Sci. Eng. A 670 (2016) 132-145

9) E.D. Levine, W.F. Sheely and R.R. Nash: Trans. Metall. AIME 215 (1959) 521-526.

10) A. Akhtar and E. Teghtsoonian: Philos. Mag. 25 (1972) 897-916.

11) S. Ando, M. Tsushida and H. Kitahara: Mater. Sci. Forum 706-709 (2012) 1122-1127

12) A. Akhtar and E. Teghtsoonian: Acta Metall. 17 (1969) 1339-1349.

13) S. Miura, S. Imagawa, T. Toyoda, K. Ohkubo and T. Mohri: Mater. Trans. 49 (2008) 952-956.

14) H. Rikihisa, T. Mori, M. Tsushida, H. Kitahara and S. Ando: Mater. Trans. 58 (2017) 1656-1663.

15) R.W. Hertzberg, R.P. Vinci and J.L. Hertzberg: Deformation and Fracture Mechanics of Engineering Materials, (John Wiley \& Sons, Inc., Hoboken, 2012) pp. 117-120.

16) H. Yoshinaga: Chumitsu Ropposho Kinzoku no Henkei Soushou, (Uchida Rokakuho Publishing Co., Ltd., Tokyo, 2007) pp. 68-72.

17) Japanese Standards Association (ed.): JIS handbook Non-Ferrous Metals \& Metallurgy: English version 2016, (Japanese Standards Association, Tokyo, 2016) pp. 113-135.
18) H. Tonda, T. Gotoh, Y. Nakashima and T. Kawasaki: J. Japan Inst. Metals 39 (1975) 351-357.

19) T. Mineta, S. Miura, K. Oka and T. Miyajima: Mater. Trans. 59 (2018) 602-611.

20) S. Kohda: Introduction to Metal Physics, (CORONA PUBLISHING CO., LTD., Tokyo, 1973) p. 156.

21) S. Miura, S. Yamamoto, K. Ohkubo and T. Mohri: Mater. Sci. Forum 350-351 (2000) 183-188.

22) S. Ando, M. Tsushida and H. Kitahara: Mater. Sci. Forum 654-656 (2010) 699-702.

23) S. Ando, M. Tsushida and H. Kitahara: The $8^{\text {th }}$ Pacific Rim International Congress on Advanced Materials and Processing, ed. by Fernand Marquis, (TMS, 2013) pp. 979-985.

24) H. Tonda and T. Kawasaki: J. Japan Inst. Metals 47 (1983) 373-374.

25) H. Kitahara, M. Tsushida and S. Ando: Mater. Trans. 57 (2016) 1246-1251.

26) T. Mineta, S. Miura, T. Mukai, M. Ueda and T. Mohri: J. Japan Inst. Met. Mater. 77 (2013) 466-472

27) R.L. Bell and R.W. Cahn: Proc. Roy. Soc. A 239 (1957) 494-521. 